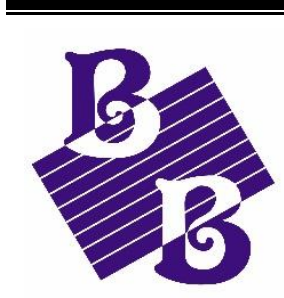

BioBacta
Journal of Bioscience and Applied Research

www.jbaar.org

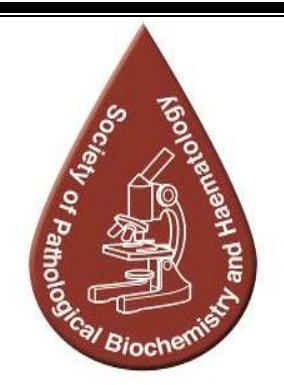

\title{
Knowledge, Attitude and Practice toward Prevention of Hepatitis B Virus Infection among Somalian Immigrant in the State of Selangor, Malaysia, and their HBV Infection Status
}

\author{
Abdirauf Mohamed Abdia ${ }^{\text {, Mohd Nazil Salleh }}{ }^{\text {* }}$ \\ ${ }^{a}$ Department of Health Sciences, Faculty of Engineering and Life Sciences, Universiti Selangor, Shah Alam City Campus, \\ Jalan Zikron A 7/A, Seksyen 7, 40000 Shah Alam Selangor, Malaysia \\ *Corresponding author: Associate Professor Dr. Mohd Nazil Salleh, Department of Health Sciences, Faculty of \\ Engineering and Life Sciences, Universiti Selangor, Shah Alam City Campus, Jalan Zikron A 7/A, Seksyen 7, 40000 Shah \\ Alam Selangor, Malaysia. Email: drnazil@unisel.edu.my. Tel: +603 -5522 3471
}

DOI: $10.21608 /$ jbaar.2019.141365

\section{Abstract}

Background: Hepatitis B virus (HBV) infection is a serious health problem that can lead to liver cirrhosis and cancer. Assessing the public knowledge, attitude, and practice towards HBV infection can be useful in planning public health policies in HBV management. Objective: The current study sought to determine the association between knowledge, attitude, and practice towards HBV infection with the HBV infection status of Somalian immigrants in Malaysia. Method: A cross-sectional study was conducted from September 2017 to April 2018 among Somalian immigrants in the state of Selangor, Malaysia. Data was collected using a validated, selfadministered structured questionnaire. Their blood samples were collected for the detection of HBV DNA using nested PCR. Descriptive statistics and chi-square analysis were done to determine this association. Result: A total of 145 participants were recruited. The majority of participants were in the age group of 20-31 (84.1\%), male $(62.8 \%)$, single (52.4\%), had an educational level of an undergraduate degree (70.3\%), and unemployed (88.3\%). The majority of the participants show good knowledge (82.8\%) and attitude (78.6\%) but generally poor practice (32.4\%) towards HBV infection. The mean knowledge, attitude, and practice scores among them were $16.9 \pm$ (4.89), $9.20 \pm$ (2.94), and $9.39 \pm$ (2.93) respectively. The sociodemographic characteristic variables and KAP of HBV were not significantly associated. Selected samples collected from the participant tested negative for HBV DNA via nested PCR assay. Conclusion: Somalian immigrants in Malaysia have a good level of knowledge and attitude but a poor level of practice towards HBV infection. All participants were negative for HBV infection.

Key Words: Hepatitis B virus (HBV), Prevention, Somalian Immigrant, Infection Status, State of Selangor.

Received date: March 1, 2019. Accepted: May 10, 2019, Published: May 11, 2019 


\section{Introduction}

Hepatitis B virus (HBV) infection is one of the major public health issues worldwide. It is the most common and serious form of infection that can progress to chronic, lifelong infection of the liver (Kim et al. 2019). According to the World Health Organization (WHO), nearly 2 million people have been reported with evidence of ongoing or previous HBV infection globally. More than 2 million people, 350 million of them suffered from chronic, lifelong infection of the virus (Abdela et al. 2016).

HBV infection targeted the liver, leading to the development of a plethora of liver diseases ranging from acute hepatitis to chronic hepatitis, liver cirrhosis, and hepatocellular carcinoma. It is estimated that $15-40 \%$ of chronic HBV carriers were susceptible to develop liver cirrhosis and hepatocellular carcinoma. Consequently, one million people die each year as a result of $\mathrm{HBV}$ infection and its complications (Noubiap et al. 2015).

Attributed to the development of a vaccine against $\mathrm{HBV}$, regions of developed nations such as North America, Northern, and Western Europe, and Australia have seen a significant reduction in the disease burden (Baig et al. 2015). These regions are considered as having low endemicity of HBV with prevalence ranging from 5 to $7 \%$ of the population and 0.5 to $2 \%$ of them are chronic carriers (Baig VN et al. 2015).

However, moderate endemic regions such as part of Eastern and Southern Europe, the Middle East, Japan, and part of South America with 10 to 60\% prevalence and 2 to $7 \%$ chronic carriers, as well as high endemic regions such as South East Asia, China, sub-Saharan Africa and the Amazon Basin with 70 to $95 \%$ prevalence and more than $8 \%$ chronic carriers, still exists due to the lack of enforcement and awareness towards the control of the disease (Coppola et al. 2015).

HBV can be transmitted through contact with infected bodily fluids that include blood, semen, and vaginal secretion (Sagnelli et al. 2014). Moreover, HBV can also be transmitted from infected mothers to their newborn babies and is believed to be a major contributor to the prevalence in high endemic regions (Adjei et al. 2016). In terms of practice, HBV is transmitted through unprotected sexual intercourse with an infected individual, sharing of needles and syringes either in health-care settings or among persons who inject drugs, or during medical, surgical, or dental procedures, or getting a tattoo, or shaving in the barbershop through the use of equipment that is contaminated with infected blood (Sagnelli et al. 2014).

By adhering to universal precautions which include using protective barriers such as gloves, vaccination, appropriate sterilization of medical equipment, and proper hospital waste management system, the spread of HBV infection can be prevented. Also, HBV cannot be transmitted by holding hands, sharing food, kissing, hugging, coughing, sneezing, or breastfeeding (Sagnelli et al. 2014).

Assessment of knowledge, attitude, and practice (KAP) towards a certain health issue is a useful tool in planning public health policies. Strategies in disease management can be tailored to maximize results by taking into account the current $\mathrm{KAP}$ of the target population. It is a valuable and most frequently used study tool in health-seeking behavior research. The study collects information on what is known, believed, and done by the member of the population concerning a particular topic (Hamissi et al. 2014).

Knowledge is usually assessed to see how 
far the community members knew regarding the biomedical concepts revolve around the topic of interest such as causes and symptoms of the disease. When the knowledge deviates from biomedical concepts, it is termed as "beliefs". People's beliefs, feelings, and values toward a particular object or phenomenon culminated into their attitude toward it (Hassan-kadle et al. 2018). Finally, the knowledge and attitude towards a disease influence their practices such as preventive measures towards a certain disease or lifestyle modification (Kim et al. 2019).

HBV can also spread via immigration, particularly within migrants from countries with a high HBV endemicity to those with a low HBV endemicity (Li et al. 2015). Like many other sub-Saharan African countries, Somalia also has high endemicity of HBV with evidence of current and past infection found in $18.9 \%$ to $29 \%$ of the population (Mansour-Ghanaei et al. 2013). On the other hand, Malaysia, despite being one of the countries located in a highly endemic region of South East Asia, has become one of the countries in Asia that have reduced the burden of HBV infection with a reported HBV prevalence of 5\% (Mesfin and Kibret 2013). The current study aims to determine the association between knowledge, attitudes, and practices (KAP) towards HBV infection among Somalian immigrants in the state of Selangor, Malaysia, and their HBV infection status.

\section{Methods}

\section{Ethical Approval}

This research has been approved by the Ethics Committee of the Faculty of Engineering and Life Science UNISEL (J150056E).

\section{Study Design}

Data on knowledge, attitude and practice toward HBV among Somalian immigrants in Malaysia and their sociodemographic characteristics were assessed through validated, self-administered structured questionnaires (Nelson et al. 2017). HBV infection status of the participants was confirmed via detection of the HBV DNA in their blood (Rajamoorthy et al. 2019). Data were collected from September 2017 to April 2018.

\section{Study Participants}

The study population was recruited from Somalian immigrants to Malaysia who reside in the state of Selangor, particularly the three different regions of Shah Alam, Serdang, and Gombak. Inclusion criteria include adults with Somalia citizenship in the state of Selangor that is older than 20 years old regardless of gender, employment, and social status. Somalian immigrants that have recurrent evidence of HBV infection, who are younger than 20 years old, that have citizenship other than Somalia, or not residing in Malaysia were excluded from the study.

\section{Data Collection}

Data was collected by using a self-administered structured questionnaire that collects information about the sociodemographic characteristics of the participants and their KAP towards the prevention of HBV. Data were collected using a personal interview with the study population. The investigator gave a brief introduction to participants before filling the questionnaire. The face validity and the reliability of the questionnaire were evaluated by conducting a pilot study with approximately $5 \%$ of the sample size (10 people).

\section{Blood Sample Collection}

To determine the HBV infection status among participants, their blood was tested for the presence of HBV DNA. Venipuncture was performed by the certified phlebotomist and $4 \mathrm{ml}$ of blood was collected in a vacutainer tube together with age and gender data. All blood sample was centrifuged and the plasma was separated. All samples were stored at $-80^{\circ} \mathrm{C}$ until analysis. 


\section{Nested Polymerase Chain Reaction}

The presence of HBV DNA in participants' blood was detected using nested polymerase chain reaction (PCR). Nested PCR is a technique that utilized two sets of primers to amplify low occurring DNA sequences. DNA from the samples was extracted using a QIAamp DNA Blood Mini Kit (QIAGEN GmbH, Hilden, Germany). Two different sets of primers (S1 and nested S2) were used to target the HBV DNA as shown in Table 1. The presence of amplified product was assessed with agarose gel electrophoresis.

Table 1. Primers used for amplification of HBV infection.

\begin{tabular}{|l|l|}
\hline Primer Name & Sequence $\left(\mathbf{5}^{\prime} \mathbf{- 3} \mathbf{\prime}^{\mathbf{}}\right.$ \\
\hline S1 forward & TCCTGCTGGTGGCTCCAG \\
\hline S1 reverse & CGTTGACATACTTTCCAATCAA \\
\hline Nested S2 forward & ACCCTGYRCCGAACATGGA \\
\hline Nested S2 reverse & CAACTCCCAATTACATARCCCA \\
\hline
\end{tabular}

\section{Data Analysis}

Data analysis was checked for comprehension and reliability. Data was entered and analyzed using IBM SPSS software version 21.0. The findings were presented as numbers and percentages for categorical data. For quantitative data, the findings were presented as mean and standard deviation. The relationship between the variables was determined using descriptive statistics. A Chi-square test was used to determine the effect of different factors on the event of HBV infection. The chi-square result with a p-value less than 0.05 was considered statistically significant and while more than 0.05 was considered to be insignificant.

\section{Results}

\section{Sociodemographic Characteristics}

A total of 145 questionnaires were distributed and 145 were received with a response rate of $100 \%$. The gender distribution was $91(62.8 \%)$ males and $54(37.2 \%)$ females. The mean age of the study participants was 21.2 (0.44) years old. Most participants were in the 21 to 30 years old age group, $122(84.1 \%)$. In terms of marital status, there were $76(52.4 \%)$ singles, $52(35.9 \%)$ married individuals, and 17 (11.7\%) divorcees. Regarding educational level, $11(7.6 \%)$ individuals had up to secondary level education, $102(70.3 \%)$ individuals had an undergraduate degree, and $32(22.1 \%)$ individuals had a postgraduate degree. The majority of the participants were students, hence, 128 $(88.3 \%)$ of them identified themselves as unemployed. The sociodemographic characteristics of the Somalian immigrants in Malaysia are shown in Table 2. 
Table 2. Sociodemographic characteristics among Somalian immigrants in the state of Selangor, Malaysia.

\begin{tabular}{|l|l|l|l|}
\hline Variable & Group & Frequency (n) & Percent (\%) \\
\hline Age (21.2 \pm 0.44$)$ & $<20$ & 4 & 2.8 \\
\cline { 2 - 4 } & $21-30$ & 122 & 84.1 \\
\cline { 2 - 4 } & $31-40$ & 17 & 11.7 \\
\cline { 2 - 4 } & $>41$ & 2 & 1.4 \\
\hline Gender & Male & 91 & 62.8 \\
\cline { 2 - 4 } & Female & 54 & 37.2 \\
\hline Marital status & Single & 76 & 52.4 \\
\cline { 2 - 4 } & Married & 52 & 35.9 \\
\cline { 2 - 4 } & Divorced & 17 & 11.7 \\
\hline Education level & Up to Secondary & 11 & 7.6 \\
\cline { 2 - 4 } & Undergraduate degree & 102 & 22.1 \\
\cline { 2 - 4 } & Postgraduate degree & 32 & 11.7 \\
\hline Working status & Employed & 17 & 88.3 \\
\cline { 2 - 4 } & Unemployed & 128 & \\
\hline
\end{tabular}

\section{Assessment of Knowledge towards Hepatitis B}

The participant's knowledge on HBV infection, etiology, transmission, and vaccination was evaluated with 24 questions related to public knowledge on HBV infection. Scoring of more than 12 was considered to be an indicator of good knowledge on HBV infection. Among the participants, 120 (82.8\%) showed good knowledge regarding $\mathrm{HBV}$ in general as well as its etiology, transmission, and vaccination. The mean knowledge score among the participants was 16.9 (4.88). Table 3 illustrates the participant's knowledge of different aspects of HBV infection. 
Table 3. Level of knowledge on HBV infection among Somalian immigrants in the state of Selangor, Malaysia.

\begin{tabular}{|c|c|c|c|}
\hline \multirow{2}{*}{ No } & \multirow{2}{*}{ Items } & Yes & No \\
\hline & & $\mathbf{N}(\%)$ & $\mathbf{N}(\%)$ \\
\hline 1. & Have you ever heard of a disease termed Hepatitis B? & $86(59.3)$ & $59(40.7)$ \\
\hline 2. & Do you know what is Hepatitis B infection? & $81(55.9)$ & $64(44.1)$ \\
\hline 3. & Do you know the causes of Hepatitis B? & $100(69.0)$ & $45(31.0)$ \\
\hline 4. & Can Hepatitis B virus infections result in chronic hepatitis and liver cancer? & $125(86.2)$ & $20(13.8)$ \\
\hline 5. & Can Hepatitis B affect liver function? & $127(87.6)$ & $18(12.4)$ \\
\hline 6. & Can Hepatitis B affect any age group? & $96(66.2)$ & $49(33.8)$ \\
\hline 7. & Can Hepatitis B be transmitted by un-sterilized syringes, and surgical instruments? & $116(80.0)$ & $29(20.0)$ \\
\hline 8. & Can Hepatitis B be transmitted by using blades of the barber/ear and nose piercing? & $115(79.3)$ & $30(20.7)$ \\
\hline 9. & Can Hepatitis B be transmitted from mother to child? & $110(75.9)$ & $35(24.1)$ \\
\hline 10. & $\begin{array}{l}\text { Can Hepatitis B be transmitted by contaminated water/food prepared by a person suffering } \\
\text { from these infections? }\end{array}$ & $47(32.4)$ & $98(67.6)$ \\
\hline 11. & Is Hepatitis B virus transmission hereditary? & $61(42.1)$ & $84(57.9)$ \\
\hline 12. & $\begin{array}{l}\text { The early symptoms of Hepatitis B are the same as cold and flu (runny nose and } \\
\text { cough) }\end{array}$ & $57(39.3)$ & $88(60.7)$ \\
\hline 13. & Do you know the treatment for Hepatitis B virus infection? & $67(46.2)$ & $78(53.8)$ \\
\hline 14. & Can Hepatitis B be self-cured by the body? & $77(53.1)$ & $68(46.9)$ \\
\hline 15. & Is vaccination available for Hepatitis B? & $122(84.1)$ & $23(15.9)$ \\
\hline 16. & Do you recommend vaccination against Hepatitis B among your family members? & $126(86.9)$ & $19(13.1)$ \\
\hline 17. & Are you vaccinated against Hepatitis B? & $121(83.4)$ & $24(16.6)$ \\
\hline 18. & Are you aware of the appropriate intervals of the Hepatitis B vaccination? & $128(88.3)$ & $17(11.7)$ \\
\hline 19. & $\begin{array}{l}\text { Do you know the precautionary measures to be taken against Hepatitis B in your } \\
\text { routine practice? }\end{array}$ & $115(79.3)$ & $30(20.7)$ \\
\hline 20. & Are you aware of the risk of exposure to Hepatitis B at the dentist? & $114(78.6)$ & $31(21.4)$ \\
\hline 21. & Do you know the symptoms of Hepatitis B infection? & $123(84.8)$ & $22(15.2)$ \\
\hline 22. & Does HBV spread by casual contact such as handshaking? & $76(52.4)$ & $69(47.6)$ \\
\hline 23. & $\begin{array}{c}\text { Do you know the mode of disease transmission? } \\
-\quad \text { Sexual intercourse } \\
-\quad \text { Blood transfusion } \\
-\quad \text { Infection needle }\end{array}$ & $\begin{array}{l}129(89.0) \\
37(25.5) \\
76(52.4) \\
32(22.1)\end{array}$ & $\begin{array}{l}16(11.0) \\
- \\
- \\
-\end{array}$ \\
\hline 24. & $\begin{array}{l}\text { What are the methods of prevention of the hepatitis B virus? } \\
-\quad \text { Avoid unprotected sex } \\
-\quad \text { Vaccination } \\
-\quad \text { Material sterilization } \\
-\quad \text { Avoid diagnosed HBV patients } \\
-\quad \text { Proper disposal of sharps } \\
-\quad \text { Avoid needle stick injury } \\
-\quad \text { Avoid food that is not well cooked }\end{array}$ & $\begin{array}{l}61(42.1) \\
39(26.9) \\
20(13.8) \\
15(10.3) \\
2(1.4) \\
5(3.4) \\
3(2.1)\end{array}$ & $\begin{array}{l}- \\
- \\
- \\
- \\
- \\
- \\
-\end{array}$ \\
\hline
\end{tabular}




\section{Assessment of Attitude towards Hepatitis B}

The participant's attitude towards HBV transmission, prevention, vaccination, and consequences was evaluated with 15 questions related to public perception towards HBV infection. Scoring of more than 7 was considered to be an indicator of a good attitude towards HBV infection. Among the participants, 114 (78.6\%) showed a good attitude towards HBV transmission, prevention, vaccination, and consequences. The mean attitude score among the participants was 9.2 (2.94). Table 4 illustrates the participant's attitudes towards different aspects of HBV infection.

Table 4. Level of attitude towards HBV infection among Somalian immigrants in the state of Selangor, Malaysia.

\begin{tabular}{|c|c|c|c|}
\hline \multirow{2}{*}{ No } & \multirow{2}{*}{ Items } & Yes & No \\
\hline & & $\mathbf{N}(\%)$ & $\mathbf{N}(\%)$ \\
\hline 1. & Do you think you can get Hepatitis B? & $102(70.3)$ & $43(29.7)$ \\
\hline 2. & Would you share a meal with an infected person? & $103(71.0)$ & $42(29.0)$ \\
\hline 3. & Should an infected person be terminated from school/work? & $101(69.7)$ & $44(30.3)$ \\
\hline 4. & Is vaccination against Hepatitis B necessary? & $107(73.8)$ & $38(26.2)$ \\
\hline 5. & Have you ever thought you could get Hepatitis B? & $82(56.6)$ & $63(43.4)$ \\
\hline 6. & Should Hepatitis B patients be allowed to work routinely? & $75(51.7)$ & $70(48.3)$ \\
\hline 7. & Should Hepatitis B patients be isolated? & $116(80.0)$ & $29(20.0)$ \\
\hline 8. & Is education effective in improving the knowledge on Hepatitis B? & $108(74.5$ & $37(25.5)$ \\
\hline 9. & $\begin{array}{l}\text { How do you deal with Hepatitis B patients? } \\
-\quad \text { I avoided dealing with them } \\
-\quad \text { I deal with them cautiously } \\
-\quad \text { I deal with them normally }\end{array}$ & $\begin{array}{l}- \\
83(57.2) \\
32(22.1) \\
30(20.7)\end{array}$ & $\begin{array}{l}- \\
- \\
- \\
-\end{array}$ \\
\hline 10. & $\begin{aligned} & \text { What will be your reaction when you found that you have Hepatitis B? } \\
&- \text { Fear } \\
&- \text { Shame } \\
&- \text { Surprise } \\
&- \text { Sadness }\end{aligned}$ & $\begin{array}{l}- \\
39(26.9) \\
15(10.3) \\
13(9.0) \\
78(53.8)\end{array}$ & $\begin{array}{l}- \\
- \\
- \\
-\end{array}$ \\
\hline 11. & $\begin{array}{l}\text { Who will you talk to about your illness? } \\
-\quad \text { Physician } \\
-\quad \text { Spouse } \\
-\quad \text { Parents } \\
-\quad \text { Child } \\
-\quad \text { Others relatives } \\
-\quad \text { Friends } \\
-\quad \text { No one }\end{array}$ & $\begin{array}{l}- \\
54(37.2) \\
5(3.4) \\
32(22.1) \\
20(13.8) \\
4(2.8) \\
4(2.8) \\
26(17.9)\end{array}$ & $\begin{array}{l}- \\
- \\
- \\
- \\
- \\
- \\
-\end{array}$ \\
\hline 12. & $\begin{aligned} \text { What } & \text { will you do if you think that you have symptoms of Hepatitis B? } \\
- & \text { Self-treatment } \\
- & \text { Going to a health facility } \\
- & \text { Going to a homeopath } \\
- & \text { Going to a traditional healer }\end{aligned}$ & $\begin{array}{l}- \\
67(46.2) \\
51(35.2) \\
3(2.1) \\
24(16.6)\end{array}$ & $\begin{array}{l}- \\
- \\
- \\
-\end{array}$ \\
\hline 13. & $\begin{aligned} \text { When you have symptoms of Hepatitis B, at what stage will you come to the health facility? } \\
-\quad \text { After self-treatment fails } \\
-\quad \text { Three to four weeks after the appearance of symptoms } \\
-\quad \text { As soon as I realized the symptoms of HBV } \\
-\quad \text { Will not see a physician at all }\end{aligned}$ & $\begin{array}{l}- \\
24(16.6) \\
34(23.4) \\
45(31.0) \\
42(29.0)\end{array}$ & $\begin{array}{l}- \\
- \\
- \\
-\end{array}$ \\
\hline 14. & $\begin{aligned} \text { How expensive do you think the diagnosis and treatment of Hepatitis B is? } \\
-\quad \text { Free } \\
-\quad \text { Reasonable } \\
-\quad \text { Somewhat expensive } \\
-\quad \text { Expensive } \\
-\quad \text { Do not know } \\
\end{aligned}$ & $\begin{array}{l}- \\
34(23.4) \\
10(6.9) \\
17(11.7) \\
19(13.1) \\
65(44.8)\end{array}$ & $\begin{array}{l}- \\
- \\
- \\
- \\
-\end{array}$ \\
\hline 15. & $\begin{aligned} \text { What will worry you the most after you are diagnosed with Hepatitis B? } \\
-\quad \text { Fear of death } \\
-\quad \text { Fear that the disease spread to a family member } \\
-\quad \text { The treatment cost } \\
-\quad \text { Isolation from society }\end{aligned}$ & $\begin{array}{l} \\
66(45.5) \\
35(24.1) \\
13(9.0) \\
31(21.4)\end{array}$ & $\begin{array}{l}- \\
- \\
- \\
-\end{array}$ \\
\hline
\end{tabular}




\section{Assessment of Practice towards Hepatitis B}

The participant's practice towards HBV screening, prevention, and vaccination was evaluated with 16 questions related to the public action in terms of controlling HBV infection. Scoring of more than 8 was considered to be an indicator of good practice towards HBV infection. Among the participants, only 47 (32.4\%) showed good practice towards HBV screening, prevention, and vaccination, tabulated in Table 5. The mean practice score among the participants was 9.4 (2.93).

Table 5. Level of practice towards HBV infection among Somalian immigrants in the state of Selangor, Malaysia.

\begin{tabular}{|c|c|c|c|}
\hline \multirow{2}{*}{ No } & \multirow{2}{*}{ Items } & Yes & No \\
\hline & & $\mathbf{N}(\%)$ & $\mathbf{N}(\%)$ \\
\hline 1. & Have you done the screening for Hepatitis B? & $89(61.4)$ & $56(38.6)$ \\
\hline 2. & Have you got yourself vaccinated against Hepatitis B & $74(51.0)$ & $71(49.0)$ \\
\hline 3. & Do you ask for the screening of blood before transfusion? & $101(69.7)$ & $44(30.3)$ \\
\hline 4. & Do you ask for a new syringe before use? & $82(56.6)$ & $63(43.4)$ \\
\hline 5. & $\begin{array}{l}\text { Do you ask your barber to change the blade/or for safety equipment for ear } \\
\text { and nose piercing? }\end{array}$ & $104(71.7)$ & $41(28.3)$ \\
\hline 6. & Do you share food/utensils/water etc. with others? & $70(48.3)$ & $75(51.7)$ \\
\hline 7. & Do you avoid meeting people? & $59(40.7)$ & $86(59.3)$ \\
\hline 8. & Will you continue and complete the treatment for the infection? & $102(70.3)$ & $43(29.7)$ \\
\hline 9. & $\begin{array}{l}\text { Have you ever participated in a health education program related to } \\
\text { Hepatitis B? }\end{array}$ & $96(66.2)$ & $49(33.8)$ \\
\hline 10. & Have you had any injuries or wound while working? & $89(61.4)$ & $56(38.6)$ \\
\hline 11. & Have you been subjected to Hepatitis B examination? & $97(66.9)$ & $48(33.1)$ \\
\hline 12. & $\begin{array}{l}\text { Have you ever accidentally splashed blood or body fluids in your mouth, } \\
\text { eyes, and nose? }\end{array}$ & $38(26.2)$ & $107(73.8)$ \\
\hline 13. & Have you been subjected to premedical examination on appointment? & $94(64.8)$ & $51(35.2)$ \\
\hline 14. & $\begin{array}{l}\text { Is there a periodical medical examination? If yes, how frequent? } \\
-\quad \text { Every one to two months } \\
-\quad \text { Every three to six months } \\
-\quad \text { Once a year } \\
-\quad \text { Do not response }\end{array}$ & $\begin{array}{l}99(68.3) \\
49(33.8) \\
34(23.4) \\
36(24.8) \\
26(17.9)\end{array}$ & $\begin{array}{l}46(31.7) \\
- \\
- \\
-\end{array}$ \\
\hline 15. & Have you received a full dose of vaccination against Hepatitis B? & $55(37.9)$ & $90(62.1)$ \\
\hline 16. & $\begin{array}{l}\text { How many doses of Hepatitis B vaccine did you receive? } \\
-\quad \text { One dose } \\
-\quad \text { Two doses } \\
-\quad \text { Three doses } \\
-\quad \text { Do not know }\end{array}$ & $\begin{array}{l}- \\
24(16.6) \\
33(22.8) \\
55(37.9) \\
33(22.8)\end{array}$ & $\begin{array}{l}- \\
- \\
- \\
-\end{array}$ \\
\hline
\end{tabular}


Association of Sociodemographic towards HBV infection scores were determined Characteristics and KAP Scores using descriptive statistics and the Chi-square test.

The relationship between the sociodemographic characteristics among the participants and the Sociodemographic characteristics were found to not outcome of their knowledge, attitude, and practice

affect the KAP scores as depicted in Table 6.

Table 6. Sociodemographic characteristics among Somalian immigrants in the state of Selangor, Malaysia.

\begin{tabular}{|c|c|c|c|c|c|c|c|}
\hline Description & $\mathbf{N}(\%)$ & $\begin{array}{l}\text { Good } \\
\text { Knowledge }\end{array}$ & P-value & $\begin{array}{l}\text { Good } \\
\text { Attitude }\end{array}$ & $\begin{array}{l}\text { P- } \\
\text { value }\end{array}$ & $\begin{array}{l}\text { Good } \\
\text { Practice }\end{array}$ & P-value \\
\hline \multicolumn{8}{|l|}{ Age } \\
\hline$<20$ & $4(2.8)$ & $3(75.0)$ & \multirow{4}{*}{0.899} & $3(75.0)$ & \multirow[t]{4}{*}{0.639} & $0(0.0)$ & \multirow[t]{4}{*}{0.388} \\
\hline $21-30$ & $122(84.1)$ & $101(82.8)$ & & $94(77.0)$ & & $41(33.6)$ & \\
\hline $31-40$ & $17(11.7)$ & $14(82.4)$ & & $15(88.2)$ & & $6(35.3)$ & \\
\hline$>41$ & $2(1.4)$ & $2(100.0)$ & & $2(100.0)$ & & $0(0.0)$ & \\
\hline \multicolumn{8}{|l|}{ Gender } \\
\hline Male & $91(62.8)$ & $76(83.5)$ & \multirow[t]{2}{*}{0.754} & $75(82.4)$ & \multirow[t]{2}{*}{0.148} & $30(33.0)$ & \multirow[t]{2}{*}{0.853} \\
\hline Female & $54(37.2)$ & $44(81.5)$ & & $39(72.2)$ & & $17(31.5)$ & \\
\hline \multicolumn{8}{|l|}{ Marital status } \\
\hline Single & $76(52.4)$ & $58(76.3)$ & \multirow{3}{*}{0.085} & $56(73.7)$ & \multirow{3}{*}{0.159} & $30(39.5)$ & \multirow{3}{*}{0.145} \\
\hline Married & $52(35.9)$ & $46(88.5)$ & & $42(80.8)$ & & $12(23.1)$ & \\
\hline Divorced & $17(11.7)$ & $16(94.1)$ & & $16(94.1)$ & & $5(29.4)$ & \\
\hline \multicolumn{8}{|l|}{ Education level } \\
\hline Up to Secondary & $11(7.6)$ & $9(81.8)$ & \multirow{3}{*}{0.723} & $7(63.6)$ & \multirow{3}{*}{0.204} & $4(36.4)$ & \multirow{3}{*}{0.174} \\
\hline $\begin{array}{l}\text { Undergraduate } \\
\text { Degree }\end{array}$ & $102(70.3)$ & $83(81.4)$ & & $84(82.4)$ & & $37(36.3)$ & \\
\hline $\begin{array}{l}\text { Postgraduate } \\
\text { Degree }\end{array}$ & $32(22.1)$ & $28(87.5)$ & & $23(71.9)$ & & $6(18.8)$ & \\
\hline \multicolumn{8}{|l|}{ Working status } \\
\hline Employed & $17(11.7)$ & $16(94.1)$ & \multirow[t]{2}{*}{0.187} & $13(76.5)$ & \multirow[t]{2}{*}{0.818} & $6(35.3)$ & \multirow{2}{*}{0.787} \\
\hline Unemployed & $128(88.3)$ & $104(81.3)$ & & $101(78.9)$ & & $41(32.0)$ & \\
\hline
\end{tabular}




\section{HBV Infection Status}

All the participants included in this study were known to be free of HBV infection. Molecular analysis for the presence of occult HBV infection was done via PCR detection of HBV DNA. Successful amplification of the HBV DNA will produce a 350 base pair product that can be seen in the agarose gel electrophoresis. All samples were tested negative for HBV DNA. None of the samples demonstrated successful amplification of the 350 base pair HBV DNA PCR product as shown in Figure 1. Hence, the association between knowledge, attitudes, and practices towards HBV infection among Somalian immigrants in the state of Selangor, Malaysia, and their HBV infection status could not be evaluated.

Figure 1. PCR Product of HBV DNA Nested PCR.

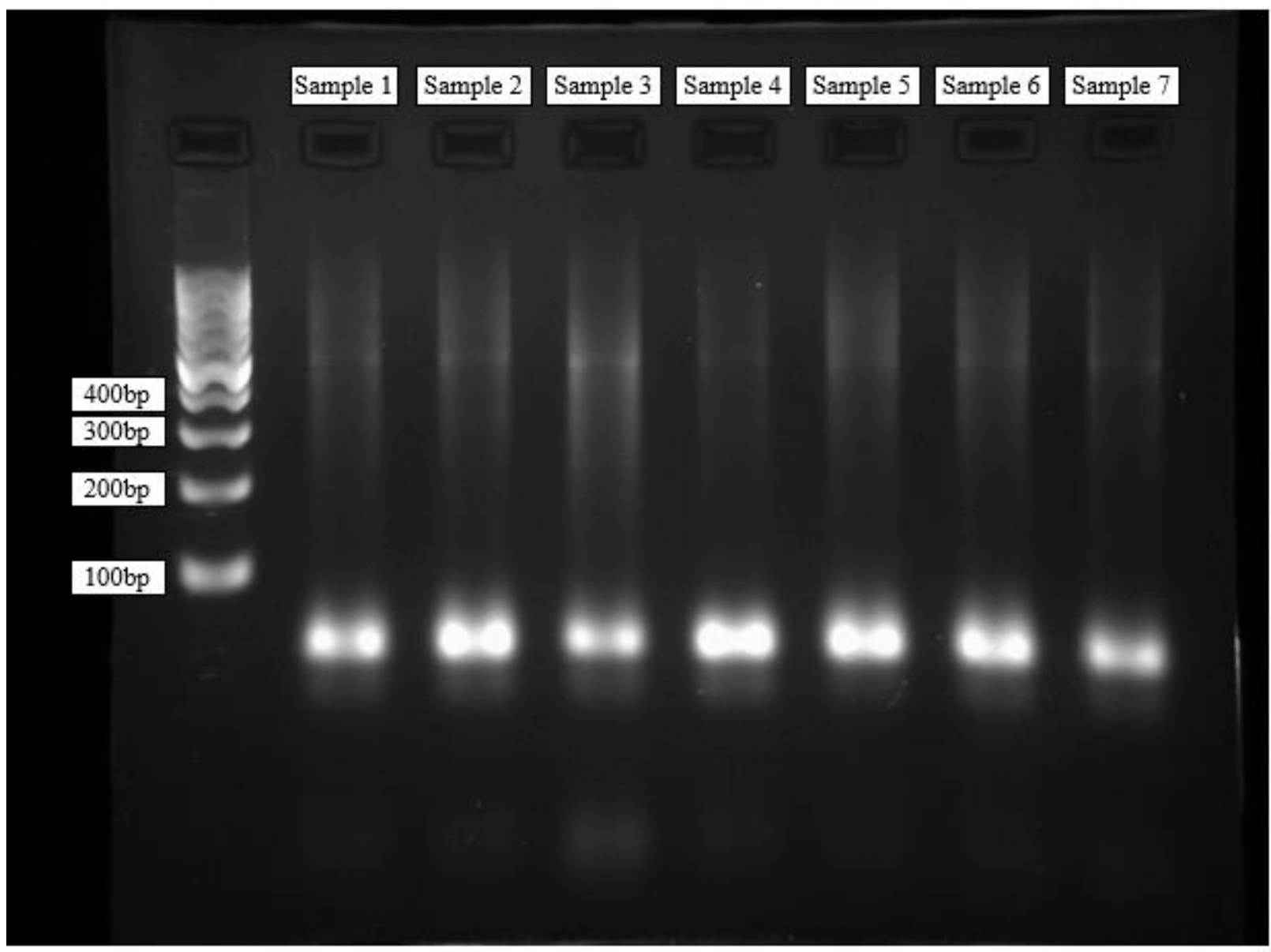




\section{Discussion}

The existence of vaccines against HBV infection, since 1982, has led to the low prevalence of HBV infection in many developed countries (Siraj, Fareed, and Mahajan 2016). However, the prevalence of HBV infection is still high in sub-Saharan Africa and southeast Asia due to the lack of awareness and action taken towards controlling the disease (Terrault et al. 2018).

Malaysia, a country located in South East Asia, is one of the few countries in Asia that has a low prevalence of HBV infection (Elbur et al. 2017). Considering the potential of $\mathrm{HBV}$ transmission via immigration, particularly within migrants from countries with a high HBV endemicity to those with a low HBV endemicity, the Malaysian government requires a mandatory health screening for all travelers within the first five days of arrival in Malaysia. This mandatory screening also applies to the Somalian immigrants, whose home country has reported prevalence of $18.9 \%$ to $29 \%$ of the population (Mansour-Ghanaei et al. 2013).

The current study sought to evaluate knowledge, attitude, and practice towards HBV infection among Somalian immigrants in Malaysia and their relationships to the HBV infection status of the Somalian immigrants. Results of the study showed an overall good level of knowledge and attitude of the participants toward HBV infection. However, a poor level of practice towards HBV infection was detected among the participants. Nevertheless, all participants were devoid of molecular evidence of HBV infection. Moreover, participant's sociodemographic characteristics also shown no association with their KAP.

Numerous studies had been done in the past to assess the level of KAP towards HBV infection in a variety of populations, mainly healthcare professionals (Haq et al. 2013). In terms of knowledge and attitude, many of the population studied demonstrates a fair level of understanding and perception towards the disease. However, vaccination compliance has been continuously identified as a gap in practice in many of these studies. In the current study, Somalian immigrants demonstrated a similar pattern, where they have good knowledge and attitude but poor practice.

A high level of knowledge on the biomedical concepts revolving around $\mathrm{HBV}$ was expected in the healthcare professional's population. This typically translates to a good attitude towards the disease. Studies focusing on the dentist, physician, healthcare workers, medical students, and dental students, (Haq et al. 2013) all revealed a fair level of knowledge and attitude towards HBV. In non-clinical university students, a study conducted among students of Fayoum University, Egypt, revealed that threequarters of the participants had a satisfactory level of knowledge and attitude towards HBV (Zampino et al. 2015), (Vahdat et al. 2014), (Wang 2009), WHO, 2018, WHO, 2019.

In the current study, $82.8 \%$ out of the 145 participants, demonstrated a good level of knowledge towards HBV. Good knowledge was apparent among the participants because a majority $(88.3 \%)$ of them were students who had prior knowledge about the infection. The mean knowledge score for the complete cross-sectional study was 16.9 (4.88). A good level of knowledge is indicated by a score of 12 . As expected, the level of attitude follows the level of knowledge with $78.6 \%$ of participants showed a good attitude towards HBV. The mean attitude score for the complete cross-sectional study was 9.2 (2.94). A good level of attitude is indicated by the score of 7 .

A sufficient level of knowledge and a good attitude towards a certain disease can lead to good practice in disease prevention and control (Kim H et al. 2019). However, many KAP studies in HBV has shown a relatively poor level of practice despite a good level of knowledge and attitude towards it. When inspected 
deeper, vaccination compliance was identified as the recurrent gap in the practice of dentists (Elbur et al. 2017), physicians, healthcare workers, medical students, and dental students. The unavailability of the vaccine in a developing country such as Ethiopia has contributed to the low vaccination practice among study populations.

In the current study, only $32.4 \%$ of the participants demonstrated a good level of practice towards HBV. More than half of the population $(62.1 \%)$ did not receive the recommended three doses of the $\mathrm{HBV}$ vaccine. However, the mean knowledge score for the complete cross-sectional study indicated a good practice with a score of 9.4 (2.93), slightly higher than the cut-off score of 8 .

In terms of $\mathrm{HBV}$ infection status, all study participants were found to be devoid of traces of HBV DNA in their blood. Nested PCR is a method that utilized two sets of primers to amplify low occurring DNA sequences. This method has been proven to be able to detect occult HBV infection in $4 \%$ of the 1000 HBV negative Iranian (Raihan $R$ et al. 2019). The negative result in Somalian immigrants in Malaysia suggests a positive correlation between good KAP and the HBV infection status among Somalian immigrants in Malaysia.

Although the finding may not be representative of the entire Somalian immigrants in Malaysia, the current study demonstrates a gap regarding practice on prevention of $\mathrm{HBV}$ among Somalian immigrants in the state of Selangor. This study can serve as a reference to urging the Somalian Ministry of Health to prioritize the awareness and education on the HBV prevention measures, particularly its vaccination program. This highlights the need to make the appropriate HBV vaccine freely available in the health centers along with educating the public, especially pregnant mothers, on the importance of vaccination against $\mathrm{HBV}$.

\section{Conclusion}

Knowledge and attitude towards HBV infection among Somalian immigrants in Malaysia were acceptable but their practice towards HBV infection was poor. Nevertheless, all of the participants were devoid of molecular evidence of HBV infection, suggesting a positive correlation between good KAP and the HBV infection status among Somalian immigrants in Malaysia.

\section{Acknowledgements}

This research was supported by an internal fund for a postgraduate project at University Selangor.

\section{Conflict of interest}

The authors have no conflicts of interest to disclose.

\section{References}

Abd El-Nasser G, Abed El baset E. Assessment of Students Knowledge and Attitude Toward Hepatitis B and C in Sohag University/Egypt. KUFA J Nurs Sci. 2013;3(1).

Abdela A, Woldu B, Haile K, Mathewos B,
Deressa T. Assessment of knowledge, attitudes and
practices toward prevention of hepatitis B virus
infection among students of medicine and health
sciences in Northwest Ethiopia. BMC Res Notes
[Internet]. 2016 Dec 19 [cited 2019 Jan 30];9(1):410.
Available from: http://www.ncbi.nlm.nih.gov/pubmed/27543117
Abiola A-HO, Agunbiade AB, Badmos KB, Lesi AO, Lawal AO, Alli QO. Prevalence of HBsAg, knowledge, and vaccination practice against viral hepatitis B infection among doctors and nurses in a secondary health care facility in Lagos state, South- western Nigeria. Pan Afr Med J [Internet]. 2016 [cited 2019 Jan 30];23. Available from: http://www.panafrican-med-
journal.com/content/article/23/160/full/ 
Adjei, Charles Ampong, et al. 2016. "Mother-toChild Transmission of Hepatitis B: Extent of Knowledge of Physicians and Midwives in Eastern Region of Ghana." BMC Public Health: 1-7. http://dx.doi.org/10.1186/s12889-016-3215-6.

Baig VN, Gupta PK, Sharma AK, Madhusudan S. Assessment of knowledge, attitude and practice about hepatitis B among Clinicians \& Medical students: a cross-sectional study. Natl J Community Med. 2015;6(2):415-22.

Coppola N, Alessio L, Pisaturo M, Macera M, Sagnelli C, Zampino R, et al. Hepatitis B virus infection in immigrant populations. World J Hepatol [Internet]. 2015 Dec 28 [cited 2019 Jan 30];7(30):2955-61. Available from: http://www.ncbi.nlm.nih.gov/pubmed/26730274

Chen CJ, Wang LY, Yu MW. Epidemiology of hepatitis B virus infection in the Asia-Pacific region. J Gastroenterol Hepatol [Internet]. 2000 May [cited 2019 Jan 30];15 Suppl: E3-6. Available from: http://www.ncbi.nlm.nih.gov/pubmed/10921373

Hamissi J, Tabari ZA, Najafi K, Hamissi H, Hamissi Z. Knowledge, Attitudes and Practice of Hepatitis B vaccination among Iranian dentists. Int J Collab Res Intern Med Public Heal. 2009;6(7).

Hassan-Kadle MA, Osman MS, Ogurtsov PP. Epidemiology of viral hepatitis in Somalia: Systematic review and meta-analysis study. World J Gastroenterol [Internet]. 2018 Sep 14 [cited 2019 Jan 30];24(34):3927-57. Available from: http://www.ncbi.nlm.nih.gov/pubmed/30228786

Kim H, Yang JD, El-Serag HB, Kanwal F. Awareness of Chronic Viral Hepatitis in the United States: An Update from National Health and Nutrition Examination Survey. J Viral Hepat. 2019 Jan 10;

Li X, Kang H, Wang S, Deng Z, Yang T, Jia Y, et al. Knowledge, Attitude, and Behavior of Hepatitis B Virus Infection among Chinese Dental Interns. Hepat
Mon [Internet]. 2015 May 23 [cited 2019 Jan 30];15(5):e25079. Available from: http://www.ncbi.nlm.nih.gov/pubmed/26045703

MacLachlan JH, Cowie BC. Hepatitis B virus epidemiology. Cold Spring Harb Perspect Med [Internet]. 2015 May 1 [cited 2019 Jan 30];5(5):a021410. Available from: http://www.ncbi.nlm.nih.gov/pubmed/25934461

Mesfin YM, Kibret KT. Assessment of Knowledge and Practice towards Hepatitis B among Medical and Health Science Students in Haramaya University, Ethiopia. Schildgen O, editor. PLoS One [Internet]. 2013 Nov 21 [cited 2019 Jan 30];8(11):e79642. Available from: https://dx.plos.org/10.1371/journal.pone.0079642

Nelson NP, Easterbrook PJ, McMahon BJ. Epidemiology of Hepatitis B Virus Infection and Impact of Vaccination on Disease. Clin Liver Dis. 2016;20(4):607-28.

\section{Raihan R, Mohamed R, Radzi Abu Hassan M, Md} Said R. Chronic Viral Hepatitis in Malaysia: \&quot; Where are we now?\&quot; Euroasian J hepatogastroenterology [Internet]. 2017 [cited 2019 Jan 30];7(1):65-7. Available from: http://www.ncbi.nlm.nih.gov/pubmed/29201775

Sagnelli, Evangelista, et al. 2014. "Epidemiology of Acute and Chronic Hepatitis B and Delta over the Last 5 Decades in Italy.” 20(24): 7635-43.

Siraj F, Fareed P, Mahajan N. Assessment of knowledge attitude and practice towards hepatitis B among health care workers in a tertiary care hospital. Int J Reprod Contraception, Obstet Gynecol [Internet]. 2016 Dec 16 [cited 2019 Jan 30];5(1):5861. Available from: http://www.ijrcog.org/index.php/ijrcog/article/view/ 501

Terrault NA, Lok ASF, McMahon BJ, Chang KM, Hwang JP, Jonas MM, et al. Update on 
prevention, diagnosis, and treatment of chronic hepatitis B: AASLD 2018 hepatitis B guidance. Hepatology [Internet]. 2018 Apr 1 [cited 2019 Jan 30];67(4):1560-99. Available from: http://doi.wiley.com/10.1002/hep.29800

Elbur, Abubaker Ibrahim, Nawaf Almalki, Abdualziz Alghamdi, and Housain A Alqarni Alqarni. 2017. "Knowledge, Attitude and Practice on Hepatitis B : A Survey among the Internet Users in Taif, Kingdom of Saudi Arabia.” 3(3): 1-7.

Ul Haq N, Hassali MA, Shafie AA, Saleem F, Farooqui M, Aljadhey H. A cross-sectional assessment of knowledge, attitude, and practice towards Hepatitis B among healthy population of Quetta, Pakistan. BMC Public Health. 2012 Aug 23;12(1):692.

Vahdat S, Hamzehgardeshi L, Hessam S, Hamzehgardeshi Z. Patient involvement in health care decision making: a review. Iran Red Crescent Med J. 2014 Jan;16(1):e12454.

Vaezjalali M, Rashidpour S, Rezaee H, Hajibeigi B, Zeidi M, Gachkar L, et al. Hepatitis B viral DNA among HBs antigen negative healthy blood donors. Hepat Mon. 2013 Mar;13(3):e6590.

Wang T. Model of life expectancy of chronic hepatitis B carriers in an endemic region. J Epidemiol. 2009;19(6):311-8.

World Health Organization. Hepatitis B [Internet]. 2018. Available from: https://www.who.int/en/newsroom/fact-sheets/detail/hepatitis-b

World Health Organization. Hepatitis B vaccination has dramatically reduced infection rates among children in Europe, but more is needed to achieve elimination [Internet]. World Health Organization; 2017 [cited 2019 Jan 30]. Available from: $\quad$ http://www.euro.who.int/en/healthtopics/communicablediseases/hepatitis/news/news/2017/04/hepatitis-b- vaccination-has-dramatically-reduced-infectionrates-among-children-in-europe,-but-more-isneeded-to-achieve-elimination

Zampino R, Boemio A, Sagnelli C, Alessio L, Adinolfi LE, Sagnelli E, et al. Hepatitis B virus burden in developing countries. World $\mathrm{J}$ Gastroenterol [Internet]. 2015 Nov 14 [cited 2019 Jan 30];21(42):11941-53. Available from: http://www.ncbi.nlm.nih.gov/pubmed/26576083 
